emerges from its present difficulties it seems reasonable to believe that a standard of efficiency of production will have been achieved such as was undreamt of in the prosperous time which formerly prevailed.

\section{Briquette Method of Reafforestation}

A somewhat novel method of sowing tree seeds is alluded to by Prof. Svend Heiberg, of the Department of Sylviculture of the New York State College of Forestry at Syracuse, in a Science Service Bulletin, dated June 29. Prof. Heiberg has been studying forestry methods in Europe, and was interested ir a new type of seed-sowing developed in Norway which he terms " planting forests by the brick instead of by the tree ". The seed bricks or briquettes are made of good soil and are $1 \frac{1}{2}$ in. $\times 1 \frac{1}{2}$ in. in size. Three or four seeds are placed at one end, near the surface. The briquette is then dipped in paraffin wax, except the side in which the seeds have been placed. The result is an easily transported product, which can be placed in the ground by means of a special tool designed for the purpose. A machine can turn out 16,000 briquettes in a day. Prof. Heiberg suggests that the idle lands of the United States may be reafforested by planting briquettes instead of trees. He has been experimenting with this new system of planting or sowing at the College, but has not yet had time to decide upon its successful possibilities. He realises that the method would only be practicable on bare land free of heavy weed growth. In the absence of any figures of cost and of data of success achieved, it is not possible to compare the cost of the method with ordinary broadcasting or patch sowing; but Prof. Heiberg is probably correct to a point in stating that "In the reafforestation of comparatively clear fields the briquette system will do away with tree nurseries. It has other important advantages. It permits the root system to develop normally and also avoids disturbance of the roots at the time of planting "- though these latter apply to all tree seed-sowing.

\section{Tuberculosis in Cattle}

THE eradication of tuberculosis from cattle herds is the subject of a recent article by James Mackintosh (J. Roy. Agric. Soc., vol. 92), who, besides describing the steps already taken in England and other countries to reduce the incidence of this disease, offers some practical recommendations as to how it may be more effectively stamped out. Although eradication by means of vaccines designed to confer immunity is still in the experimental stage, the testing and separating of reactors from non-reactors has met with success in northern European countries and seems to be the most hopeful method for adoption in Great Britain. Greater uniformity is, however, desirable in the application and interpretation of these tests. The measures taken under the Tuberculosis Order, 1925, to destroy all animals suffering from 'open' tuberculosis having failed to attain their object in time to be of real value, amplification of the order is recommended so as to ensure a general systematic inspection of cattle, by means of which tubercle-free beef and dairy herds may be built up, with a possible development in the future of definite 'accredited" areas. In this respect the Milk (Special Designations)
Order has been of definite use by providing the only official recognition in Great Britain for herds which have been tested and contain no reactors. The practicabihty of such a scheme as that issued by the National Veterinary Medical Association is made evident and the cost, if shared by the State, the local authorities, and the farmer, should not be heavy, whereas the benefit to the cattle industry and the community in general would be very considerable.

\section{Cockles of the Thames Estuary}

In the Southend Standard for Aug. 4 and 11, Mr. Laurence Wells describes the local cockle industry, and has collected much valuable information " The Cockle Industry of Leigh." Part I., "Early Use of the Cockle as Food and the Rise of the Industry at Leigh. on-Sea". Part II., "Natural History, Distribution, and Economics"). The natural knowledge of the fisherman is extensive. From experience and from observation he has acquired an intimacy with the ways of the cockle which would put many a naturalist to shame. Spawning time, free-swimming larvæ and the effects of the weather on them, their growing stages, and the strange sounds made by the young under the sand are all known to them. To the different parts of the animal he gives special names. He knows that if conditions are unfavourable the cockles may migrate to more pleasant surroundings. Cockles have been collected at Leigh for more than 150 years. To-day the industry is thriving and affords work for a number of men and women. The sandbanks and flats of the Thames estuary afford a habitat admirably suited to the needs of these bivalves, from Shoebury Sands for the whole length of the Maplin and Foulness Sands, known collectively as the "Maplins". The Leigh men also work along the Kent side as far as the Whitstable Flats; for 60,000 cwt. of cockles, minus the shells, are demanded from them annually, valued at $£ 11,000$. The boats are of a special design and peculiar to Leigh. The cockles are collected with a special rake and are cooked, according to Iaw, in a steam oven, before being sent to market. Apart from the sale of the cockles themselves, there is a thriving industry in by-products from the shells. A complete account of the cockle, both historical and biological, is given in Mr. Wells's interesting article.

\section{Electric Power and Village Industries}

The 'Sofina' (Société Financière de Transports et d'Entreprises Industrielles) controls a large number of industrial undertakings in all parts of the world. In its third annual report, interesting data are given of the rapid increase in the rate of the substitution of small electric motors in place of hand power in certain districts in France. In the St. Etienne district, for example, the small workshops have increased more than fifty times during the last seven years. The number of looms in 1925 was 214 , but it has now increased to more than 11,000 . In the Roanne district, the number of family weaving workshops has trebled. in nine years. Home workshops for machining cycle parts have increased greatly all over France. It is pointed out that this substitution has enabled the

No. 3280, VoL. 130] 